\author{
(online) $=$ ISSN $2285-3642$ \\ ISSN-L = $2285-3642$ \\ Journal of Economic Development, Environment and People \\ Volume 8, Issue 2, 2019 \\ URL: http://jedep.spiruharet.ro \\ e-mail: office jedep@spiruharet.ro
}

\title{
Development of the Property Marketing Strategy; Case Study at Risma Jihan Akbar Housing Developer, Bekasi - West Java
}

\author{
Dina Kurnia Sari ${ }^{1}$, Dhian Tyas Untari*2, M Fadhli Nursal ${ }^{2}$, Neng Siti Komariah² \\ ${ }^{1}$ Student of Faculty Of Economic, Bhayangkara Jakarta Raya University, Bekasi - Indonesia \\ ${ }^{*}$ Lecture of Faculty Of Economic, Bhayangkara Jakarta Raya University, Bekasi - Indonesia \\ *Email Corespondent Author: tyas_un@yahoo.co.id
}

\begin{abstract}
Bekasi is one of the buffer zones that has a fairly high population density, population density will be followed by high demand for property / houses. Based on this background, the research aims to develop a property marketing strategy with a case study on Risma Jihan Akbar (RJA). Mix method was used in this study, by involving consumers and management of RJA as respondents. Processing data using the EFAS/IFAS and Grand Strategy Matrix. The results of the study show that RJA is currently quite good in its marketing strategy, however, the very narrow segmentation causes RJA to be less well known to the public.
\end{abstract}

Keywords: Property Sector, Housing, Bekasi, West Java

JEL Codes: 129

How to cite: SARI, D., UNTARI, D., \& NURSAL, M. (2019). Development of the Property Marketing Strategy; Case Study at Risma Jihan Akbar Housing Developer, Bekasi - West Java. Journal of Economic Development, Environment and People, 8(2), 6-13. doi:http://dx.doi.org/10.26458/jedep.v8i2.618

\section{Introduction}

In the past 5 years, the property business in Bekasi has become very tempting. Indonesia Watch property reports that the growth of residential property sales in Bekasi in the fourth quarter of 2015 reached $72.01 \%$, this was strengthened by revelation (Aceng Solahudin, 2015) as more investors began to look at investment potential in Bekasi. The general assumption that economic decision always have an ecological inmpact (Grobmann et al, 2017). The conversion of land into housing often creates its own conflictThe large number of jobs in the Bekasi area makes a lot of housing (Vos, 2016; Untari et al, 2017)

The city of Bekasi is also one of the choice of residence for workers who work in Jakarta and other surrounding areas. Despite being an industrial area, the city of Bekasi has been dominated by housing. It is 


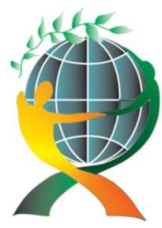

\author{
(online) $=$ ISSN $2285-3642$ \\ ISSN-L = $2285-3642$ \\ Journal of Economic Development, Environment and People \\ Volume 8, Issue2, 2019 \\ URL: http://jedep.spiruharet.ro \\ e-mail: office jedep@spiruharet.ro
}

evident that $90 \%$ of the Bekasi area is dominated by housing, $4 \%$ becomes an industrial area, $3 \%$ is a trading area, and the rest is made into other buildings. The population in Bekasi, which continues to increase from year to year according to the statistics center of the city of Bekasi, projects that the population in the Bekasi region will reach 3.2 million by 2020. This number increases to 0.3 million compared to the current population of 2.9 million.

Due to the increasing number of residents in Bekasi, the need for automatic housing has also increased. Where Act No. 4 of 1992 The house is a building that functions as a residence or residence and a means of fostering a family (Anonim, 2007). In a broad sense, housing is not only a building, but also a place of residence that meets the conditions of a decent life, viewed from various aspects of people's lives (Frick and Mulyani, 2006). In addition to the house as a place to live, the house is also a place to socialize with the surrounding environment, where housing is a collection of houses that function as a residential environment. as a residential environment, housing is equipped with environmental infrastructure and facilities (Agus Sadana, 2014). To meet the need for housing in the city of Bekasi there are several residential property developers, where the property companies aim to understand the wants and needs of consumers so that the product or service is acceptable to consumers. Therefore marketing is required to be able to understand the main problems in their field. In order to be able to provide a clear and directed picture of what the company is doing and develop a strategy in order to achieve company goals (Danang Sunyoto, 2012).

The marketing strategy must be able to provide a clear and directed picture of what the company will do in using every opportunity or opportunity in several target markets, to achieve the success of marketing activities carried out by a company, namely the target target, and marketing reference carried out (marketing mix) for the target market (Sofian Assauri, 2015: 167-168). In order for the marketing strategy to go according to plan there is a marketing mix which is a set of tactical and controlled marketing tools, which are integrated by the company to produce the desired response. According to (Kotler and Armstrong, 2012: 62) in the marketing mix there is a set of marketing tools known as $4 \mathrm{P}$, namely products, prices, places, and promotions. Whereas in service marketing has several additional marketing tools known as 7P, namely people, physical facilities and processes.

In marketing globally, the service aspect cannot be separated from the concept of product sales, as well as the developer companies. In addition to the conventional marketing mix known so far, the aspects of people, process, and physical evidence are important in the development of home-based businesses. People are a major asset in the service industry, especially people who are high performance employees. Consumer needs of high-performing employees will cause consumers to be satisfied and loyal. The ability of knowledge (knowledge) is good, will be a basic competency in the company's internal and good imaging outside. Another important factor in people is attitude and motivation from employees in the service industry. The moment of truth will occur when there is contact between employees and consumers. Attitude is very important, can be applied in various forms, such as employee appearance, voice in speech, body language, facial expressions, and words. While employee motivation is needed to realize the delivery of messages and services offered at the expected level. 


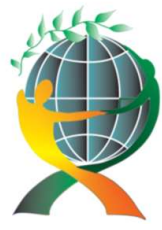

\author{
(online) $=$ ISSN $2285-3642$ \\ ISSN-L = $2285-3642$ \\ Journal of Economic Development, Environment and People \\ Volume 8, Issue 2, 2019 \\ URL: http://jedep.spiruharet.ro \\ e-mail: office jedep@spiruharet.ro
}

Process, service quality is very dependent on the process of delivering services to consumers. Given that the service company drivers are the employees themselves, then to guarantee service quality (quality assurance), all company operations must be carried out in accordance with standardized systems and procedures by employees who are competent, committed, and loyal to the company where they work. And physical evidence is part of physical evidence, the characteristics of which are value-added requirements for consumers in service companies that have character. Attention to the interior, building equipment, including lightning systems, and spacious layout are important concerns and can affect the mood of visitors. Buildings must be able to create an atmosphere by paying attention to ambience so as to provide experience to visitors and can provide added value for visitors, especially being the main requirement for service companies with special market classes.

PT. Gemilang Rizqi Efendi Development (GRED) is a private company engaged in the property sector. Based on the deed of incorporation No.146, the intent and purpose of the establishment of PT. Gemilang Rizqi Efendi Development (GRED) is to carry out business types in the field of building houses, shop houses, kiosks, and contractor services. Muhamad Efendi is the founder of this company which began in 2016 . With his capital skills and experience in the business world he is determined to seriously build a company that moves in the property sector. Established since December 29, 2016, since its inception PT. GRED has completed a house construction project in the Bekasi area, and continues to develop new housing projects. The company is currently developing a property business in the Indramayu area, West Java to build subsidized housing and commercial housing.

Based on the background of the above problems, the authors are interested in conducting research with the title "Marketing Strategy with SWOT Matrix at PT. Gemilang Rizqi Efendi Development (Case Study: Risma Jihan Akbar's Housing Developer) ". Thus the purpose of the research is to design the right marketing strategy for the housing of Risma Jihan Akbar (RJA).

\title{
2. Methodology
}

\subsection{Design Research}

Every scientific work is made in accordance with his research methodology. In research must understand the research method that is the scientific way to obtain data with specific purposes and uses (Sugiyono, 2016: 2). In the research approach is divided into two studies, namely qualitative and quantitative descriptive research. In this study using mixed methods namely qualitative and quantitative (Mix Method). Mix method is a research method by combining two research methods at once, namely qualitative and quantitative in a research activity, so that more comprehensive, valid, reliable and objective data will be obtained (Sugiyono, 2011: 18).

This research uses a gradual mixed technique that is, researchers combine data found from one method to another. this strategy can be done by interviewing first to get qualitative data then followed by quantitative data, in this case using a questionnaire. Finally, documentation, documentation in question is to help the author complete the results of the study.

\subsection{Research Conceptual Model}




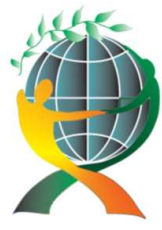

\author{
(online) $=$ ISSN $2285-3642$ \\ ISSN-L = $2285-3642$ \\ Journal of Economic Development, Environment and People \\ Volume 8, Issue2, 2019
}

URL: http://jedep.spiruharet.ro

e-mail: office jedep@spiruharet.ro

The conceptual model of research is the concept of how the theory relates to various defined factors. The conceptual model in this study is

\title{
PT Risma Jihan Akbar
}

\section{SWOT Analysis}

1. Strenghts and Weakness)

2. Oppurtunity dan Threats
Marketing Strategy

1. Product

2. Price

3. Place

4. Promotion

Fig. 1 : Model of Research

Population is a generalization area consisting of objects or subjects that have certain qualities and characteristics determined by researchers to be studied and then conclusions drawn (Sugiyono, 2016: 80). The subjects of this study were marketing and consumers who bought a house in a residential area, RJA, which had a Housing Ownership Loan (HOL) contract.

The model used in sampling is quota sampling which includes non-probability sampling techniques. Quota sampling is sampling from a population that has certain characteristics to the desired number (Sugiyono, 2016: 85). Non-probability sampling is a sampling technique that does not provide equal opportunities or opportunities for each element or member of the population to be selected as a sample (Sugiyono, 2016: 84). This sample selection is due to limited time and research funding. Data collection is done by distributing questionnaires. The number of samples used in this study are 41 . Based on the calculations of Slovin model, the sample size which was rounded up to 37 respondents was obtained.

In this study using the EFAS IFAS Matrix (Strength, Weakness, Opportunity, Threats) and Grand Strategy Matrix,a form of analysis in the management of a company or in an organization that can systematically help in the business of preparing a mature plan to achieve goals, both short and long term goals (Untari, 2016).

\section{Result And Discussion}

Based on questionnaire recapitulation distributed to 37 respondents, the results are as follows;

Table 1. Profile of Respondents

\begin{tabular}{|c|c|l|c|l|c|}
\hline \multicolumn{2}{|c|}{ Gender } & \multicolumn{2}{c|}{ Education } & \multicolumn{2}{c|}{ Ages } \\
\hline \multirow{2}{*}{ Male } & \multirow{2}{*}{21} & High School & 9 & Below 25 & 4 \\
\cline { 3 - 6 } & & Diplom & 11 & 26 th $-35^{\text {th }}$ & 13 \\
\hline \multirow{2}{*}{ Female } & \multirow{2}{*}{16} & Bachelor & 15 & 36 th $-45^{\text {th }}$ & 15 \\
\cline { 3 - 6 } & & Postgraduate & 2 & Above 45 & 5 \\
\hline
\end{tabular}




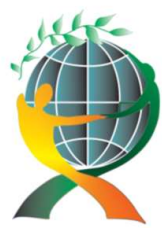

\author{
(online) $=$ ISSN $2285-3642$ \\ ISSN-L = $2285-3642$ \\ Journal of Economic Development, Environment and People \\ Volume 8, Issue 2, 2019
}

URL: http://jedep.spiruharet.ro

e-mail: office jedep@spiruharet.ro

Resources : Process data, 2019

In table 1 shows that the majority of respondents in PT RJA are Male; 56.75\%, and the remaining 43.25 are Female. This shows that in general, culture in Indonesia where men are leader of family, and have more responsibilities to meet family needs, so the majority of respondents (consumers) in the study are men (Male)

In the aspect of education, the majority have Bachelor degrees; $45.5 \%$, then Diploma; as much as $29.7 \%$ and post-graduate education is a minority; only $0.05 \%$. And in the age aspect, the majority are 36th - 45th years later the second most are 26th-35th. Where is this age is a well-established age and has a wealth so the need to own a house is very large, when compared to the age under 25 years. Whereas the age above 45 is very small, this is due to the procedure of the Bank related to the filing of a Housing Ownership Loan $(\mathrm{HOL})$, where the age of 45 years is considered to be the maximum age for submitting $\mathrm{HOL}$.

Table 2. IFAS Matrix

\begin{tabular}{|c|c|c|c|c|}
\hline No & Strength & Weight & Rank & Total \\
\hline 1 & The design of the house is quite interesting & 0,05 & 3 & 0,15 \\
\hline 2 & Layout of room use is quite efficient & 0,13 & 2 & 0,26 \\
\hline 3 & The quality of building materials is quite good & 0,11 & 4 & 0,44 \\
\hline 4 & Cooperate with many banks related to submitting $\mathrm{HOL}$ & 0.09 & 2 & 0,18 \\
\hline 5 & The customer service officer understands the product well & 0,08 & 1 & 0.16 \\
\hline 6 & The indent period of the house is not too long & 0,14 & 4 & 0,56 \\
\hline \multicolumn{4}{|c|}{ TOTAL } & 1,75 \\
\hline No & Weakness & Weight & Rank & Total \\
\hline 1 & Prices are quite expensive & 0,08 & 3 & 0,24 \\
\hline 2 & Promotions are less aggressive & 0,15 & 2 & 0,3 \\
\hline 3 & The submission procedure takes a long time & 0,10 & 2 & 0,2 \\
\hline 4 & Housing location that is a bit far from the city & 0,07 & 1 & 0,14 \\
\hline \multicolumn{4}{|c|}{ TOTAL } & 0,88 \\
\hline
\end{tabular}

Resources : Process datas, 2019

Based on the results of the questionnaire regarding the internal aspects; Prices, Products, Promotions and Place and External aspects; Willingness to pay, politics, economic and culture. Then a number of things become Key Factors and are inputted in the following EFAS / IFAS Matrix.

Based on the results of the analysis on the IFAS Matrix, the total score was 2.63 and EFAS 2.05. This shows that, in general, internal factors are more influential in RJA's business processes; when compared with external factors. In more depth, RJA has far greater strength than its weaknesses, but external factors have greater challenges than the opportunities it has. To describe the strategy that can be done, the score results on the EFAS / IFAS matrix will be described in the following Grand Matrix Strategy. 


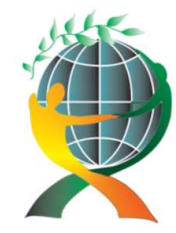

\author{
(online) $=$ ISSN $2285-3642$ \\ ISSN-L = 2285 - 3642 \\ Journal of Economic Development, Environment and People \\ Volume 8, Issue2, 2019
}

URL: http://jedep.spiruharet.ro

e-mail: office jedep@spiruharet.ro

Table 3. EFAS Matrix

\begin{tabular}{|l|l|l|l|r|}
\hline No & Opportunity & Weight & Rank & Total \\
\hline 1 & The population of Bekasi people is quite high & 0,12 & 2 & 0,24 \\
\hline 2 & Many growing industrial estates in Bekasi & 0,09 & 3 & 0,27 \\
\hline 3 & Bekasi still has extensive land for property development & 0,17 & 1 & 0,17 \\
\hline 4 & Bekasi grows as a Megapolitan area & 0,1 & 1 & 0,1 \\
\hline \multicolumn{2}{|c|}{ TOTAL } & Weight & Rank & Total \\
\hline No & Threat & 0.19 & 3 & 0,57 \\
\hline 1 & The ability to buy the people of Bekasi is not too high & 0.13 & 2 & 0,26 \\
\hline 2 & $\begin{array}{l}\text { The culture of the native people of Bekasi with a large } \\
\text { family tends to invite the child's family to live together }\end{array}$ & & 0,24 \\
\hline 3 & The high level of competition for land housing in Bekasi & 0,06 & 4 & 0,12 \\
\hline 4 & Land housing substituted by vertical housing & 0,06 & 2 & 0,08 \\
\hline 5 & Regulation of providing subsidized housing at low prices & 0,08 & 1 & $\mathbf{1 , 2 7}$ \\
\hline
\end{tabular}

Process datas, 2019

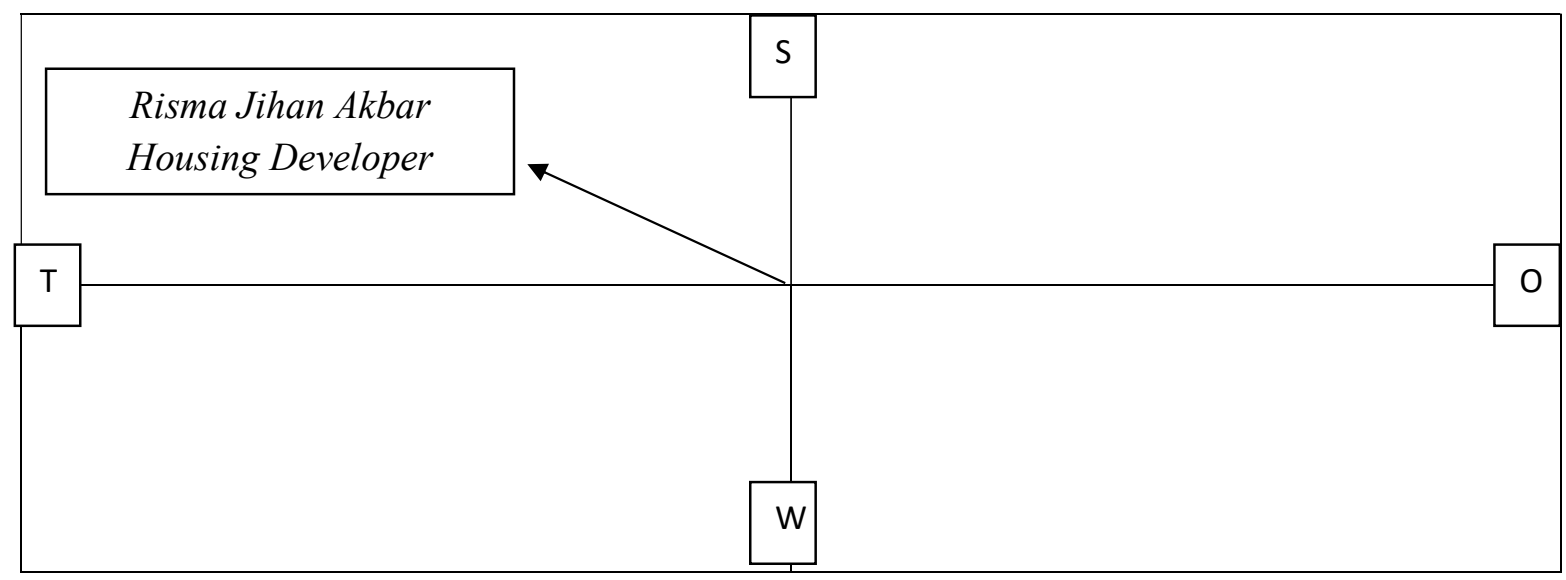

Figure 1. Grand Matrix Strategi

Resources : Process Data, 2019

Based on the description on the Grand Matrix Strategy, it appears that RJA has a fairly weak competitive position (Quadrant 2). This is because RJA has considerable strength, but the external challenges faced are also quite strong when compared to the opportunities they have. So that a fairly rational alternative strategy to do is: Market Penetration, Product Development and Horizontal Integration. The explanation of the three strategies is as follows: 


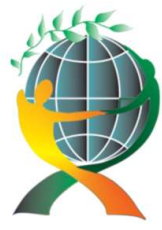

\author{
(online) $=$ ISSN $2285-3642$ \\ ISSN-L = $2285-3642$ \\ Journal of Economic Development, Environment and People \\ Volume 8, Issue 2, 2019 \\ URL: http://jedep.spiruharet.ro \\ e-mail: office jedep@spiruharet.ro
}

1. Market Penetration. RJA plays in the middle to lower segmentation market, so RJA must be able to better explore the needs and desires of consumers in its market segment. Of course the preference of the middle and lower segments is different from the middle to lower segments. The middle to upper segment requires more security, requires complete social facilities, adequate road area, and the upper middle community needs an existence or recognition that the housing has a good brand, so in addition to building infrastructure, RJA must also build a good brand in the community so that can grow pride like its inhabitants.

2. Product Development. RJA must be able to innovate by creating a type of "developing house", so that at a minimal cost, it can provide good quality products, besides that consumers can be more free to develop houses according to their preferences.

3. Horizontal Integration. RJA can cooperate with Property Marketing to expand market coverage and cooperate with supplyers of building materials to reduce production costs.

\title{
4. Conclusion
}

Based on the results of this study concluded that RJA enough strength in running its Business in the housing sector. But the value of the threats and obstacles they have is also quite large. So that three things that need to be improved in developing their marketing strategy are by penetrating the market; dig deeper into the market that has been formed, new product development; recognize market needs and desires and implement them and horizontal penetration to develop market coverage and reduce operational costs.

Seeing the state of the company empirically, where capital and human resources are still not maximized, the market penetration strategy and horizontal integration strategy are two realistic strategies to implement. Market penetration by maximizing existing resources to explore and process established markets, and horizontal integration to reduce corporate operational costs.

With these two alternative strategies, the company can focus more on empowering the company's resources to dominate the market according to its segment and maximize the company's profits to be able to develop the housing market more broadly.

Research on marketing strategies is needed in the development of the property sector, especially in Bekasi. It's just that so far (including the research I've done) is only limited to 4P, while in the housing marketing aspect process, people and physical evidence will also determine the success of housing marketing in market penetration. Therefore, the next researcher is expected to be able to involve these three aspects in his research. Besides land conversion that will disrupt the ecology of both biotic and abiotic, including the social environment, the development of the green marketing concept in marketing and housing development is urgently needed.

\section{References}

[1] Anonim. (2007). UU No. 4 Tahun 1992 tentang Perumahan dan Permukiman. Jakarta.

[2] Arikunto, S. (2013). Prosedur Penelitian: Suatu Pendekatan Praktik. Jakarta: Rineka Cipta. Hal. 221.

[3] Assauri,A. (2015). Manajemen Pemasaran. (Jakarta: Rajawali Pers, 2015), hal. 167-168.

[4] Freddy Rangkuti. (2008). Analisis SWOT Teknik Membedah Kasus Bisnis. hal. 51. 


\author{
(online) $=$ ISSN $2285-3642$ \\ ISSN-L = 2285 - 3642 \\ Journal of Economic Development, Environment and People \\ Volume 8, Issue2, 2019 \\ URL: http://jedep.spiruharet.ro \\ e-mail: office jedep@spiruharet.ro
}

[5] Frick dan Mulyani. (2006). Arsitektur Ekologis. Seri eko-arsitektur2. Yogyakarta: Kanisius.

[6] Ghozali. (2005). Aplikasi Analisis Multivariate dengan SPSS. Semarang: Badan Penerbit UNDIP. Hal. 46.

[7] Gorbmann, K. Padmanabhhan,M. Afiff, S. (2017). Gender, Ethicity and Enviromnetal Transformation in Indonesia and Beyond. Austrian Journal of South-East Asian Studies. 10(1). P.1-10

[8] Idrus, Muhammad. (2007). Metode Penelitian Ilmu-ilmu Sosial (Pendekatan Kualitatif Dan Kuantitatif). (Yogyakarta: UII Press Yogyakarta).

[9] Kotler dan Amstrong. (2012). Prinsip-prinsip Pemasaran. Jakarta: Erlangga. Edisi ke-13, Jilid 1 hal. 62.

[10] Sadana, A. (2014). Perencanaan Kawasan Pemukiman. Graha Ilmu. Yogyakarta.

[11] Solahudin, A. (2015). Properti Indonesia. [Online]. Tersedia : https://www.propertyindonesia.co.id/properti-dibekasi-pertumbuhan mencapai-7201/. Diakses 17 Februari 2019.

[12] Sugiyono. (2011). Metode Penelitian Pendidikan Pendekatan Kuantitatif, Kualitatif, Dan R\&D. Bandung: Alfabeta. Hal. 18.

[13] Sugiyono. (2016). Metode Penelitian Pendidikan Pendekatan Kuantitatif, Kualitatif, Dan R\&D. Bandung: Alfabeta. Hal. 2.

[14] Sugiyono. (2016). Metode Penelitian Kuantitatif, Kualitatif, dan R\&D. Alfabeta; Jakarta.

[15] Sunyoto, D. (2012). Dasar-Dasar Manajemen Pemasaran, CAPS: Yogyakarta.

[16] Untari, D.T. (2016). The Potential Development of Betawi Culinary as an Ecotourism Product in Jakarta. Binus Business Review, 7(3). P. 275-280

[17] Untari, D.T. Avenzora, R. Darusman, D. Prihatno, J. 2017. Betawi Culinary; Sosio-Cultures Frame of Multi Communities in Jakarta. Advanced Science Letters, 23(9). P 64-76

[18] Umar, Husein. (2008). Metode Penelitian Untuk Skripsi Dan Tesis Bisnis. Jakarta: PT. Rajagrafindo Persada. Hal. 65.

[19]___, GRED Properti. [Online]. Tersedia di: https://gredproperti.id/tentang-kami/. Diakses 13 Februari 2019.

[20]___ Badan Pusat Statistik Kota Bekasi. https://bekasikota.bps.go.id/. Diakses 17 Februari 2019.

[21] Vos, RE. (2016). Multi-Functional Lands Facing Oil Palm Monocultures: A Case Study Of a land Confliic in West Kalimantan Indonesia. Austrian Journal of South-East Asian Studies. 9(1). P. 11-32. 